\title{
Pub Culture: State Authority and Alternate Religiosity in Indonesian Pesisir
}

\section{Fathimatuz Zahra}

STAI Pati

email: ima59/ |4@yahoo.com

\begin{abstract}
The image changing of Pati from a religious city to a pub culture city has ensued for fifteen years. Thus, the efforts of restoring the condition will not be easy. Previously, the pubs were used as family pubs. However, nowadays, the number of the pubs has increased.Violence was often used by some religious organizations to solve the problem. Nevertheless, this effort did not give any significant effects. In this article, the religiosity of pub culture is formulized. The result of this study is expected to be one of the concrete solutions for restoring the image of Pati.
\end{abstract}

\section{Keywords:}

Religiosity, Pub-culture, Culture

\section{Introduction}

Pati is a small town in Central Java. It is famous as a pension city and paranormal city. However, recently, Pati is also known as a city of thousand pubs. The problem is that the pubs in Pati are used as prostitution places. Besides worrying, the emergence of the pubs has also impacted on the increasing rates of divorce in Pati. Previously, the pubs were used as family pubs. However, nowadays, the number of the pubs has increased. Indeed, the owners of the pubs also provide the pubs with pub-guides. Consequently, considering these factors, the role of the religiosity aspect is needed in order to solve this social problem. 
Several efforts have been done in order to restore the image of Pati. However, violence was often conducted by some religious organizations. In fact, this effort did not give any significant effects. On the other hand, the local government had finally decided to close all the pubs in Pati but some people considered that this decision was not an effective solution (Tanner \& Mitchell 2016).

In order to conduct more effective solution, the religiosity of pub culture is needed to be formulized (Gunby et al. 2017; Maginn \& Ellison 2017). The result of this study is expected to be one of the concrete solutions for restoring the image of Pati. Government may close the pubs but cannot remove the addictive effects of the pubs. This is not merely a matter of economic, moral, and religiosity. The question about how this kind of business may run legally is also raised. Thus, it needs a subtle effort to solve the problem, i.e. with religiosity.

Religiosity is considered as a concept which is able to overcome the lives of all human beings. There have been many attempts in defining and measuring religiosity although scholars believe that there will never be any satisfactory definition about this. However, some scholars provide the basic understanding about what religiosity is. English and English (1958) suggest that religion is:

"A system of attitudes, practices, rites, ceremonies and beliefs by means of which individuals or a community put them to relation to God or to a supernatural world, often to each other, and derive a set of values by which to judge events in the natural worlds" (English \& English 1958).

The concept of spirituality is an innate element of human beings and integral aspect of human development. Its nature is relational: the expressions of the dependability that an individual experiences to self (as in inner self) and everything that is other than self. Spirituality complements, integrates and balances the rational and emotional aspects 
of humans (Souza 2009; Gallardo-Peralta 2017; Creighton-Smith et al. 2017; Pathan 2016).

Principe (1983) examines the history of the use of the term "spirituality", and concludes that the definition of "spirituality" involves three levels. They are: (1) people's individual qualities, (2) people's way of life, and (3) scholars' study of the first two levels (Ambrose 2006).

During the late of the twentieth century, the term "religiosity" was used to refer to an organized system of beliefs and rituals which is associated with an institutional structure; while the term "spirituality" was used to refer to a personal quest or connection occurred either within or outside formal religion (Perrin 2014). William James (1902-1999), frequently referred to as the father of psychology, wrote that religiosity refers to "the feelings, acts, and experiences of individual men in their solitude, so far as they apprehend themselves to stand in relation to whatever they may consider the divine" (Perrin 2014). Stark and Glock (1968), in their influential sociological model of religiosity, identify five dimensions of religious commitment including: (1) ideological, which refers to the beliefs that a religious person holds, (2) practice, which refers to engaging in acts such as church services, (3) experience, which refers to one's feeling of closeness to, or power of, God, (4) knowledge, which refers to basic tenets of a particular religion, and (5) consequential, which refers to the manifestation of the previous four dimensions in one's day to one day behavior (Perrin 2014).

\section{The Era of the New Ages}

In order to face the challenges of each era, progress endowed with a change in the existing order in society, thoughts, patterns of life, and patterns in addressing the religious ways is needed (Makela \& Petsche 2013; Dunbar-Hall 2011; Warden et al. 2017). 
The effect of modernization in most countries during the nineteenth and early twentieth centuries was to create a level of absolutism which is greater than the previous era (Lewis 2010). The disappointment of the bourgeoisie encouraged the thoughts of the middle and upper-middleclasses in four ways. First, through quietism: "religion" or spirituality is presented as properly involving the enjoyment of one's life in ways that it must not upset the state, the economy, the empire, which take precedence over any "autonomy" afforded the individuals (Martin 2014). Second, through consumerism: individual freedom of choice is sacred matter, such as the pursuit of distinction via the consumption and display of consumer goods which are naturalized or seen as divinely ordained. Third, through practices: individual is encouraged to adjust him or herself to the latter when conflict arises (Martin 2014; Elias et al. 2015). In this case, the problem of PK (Pemandu Karaoke- or Pub Guides) is considered as part of this third classification. Fourth, through the assignment of responsibility to the individual: because individuals are presented as already having the resources for material, economic, or psychological success at hand; failure or suffering is assigned to individuals not to the social structure (Martin 2014; Plambech 2017).

Based on Berger theory, the fundamental dialectic process of society consists of three moments: externalization, objectivication, and internalization. Externalization is the ongoing outpouring of human being into the world, both in the physical and the mental activity (Berger 2011). Objectivication is the attainment by the products of this activity (again both physical and mental) of a reality that confronts that original producers as a facticity external to and other than themselves. Internalization is the re-appropriation by men of this same reality, transforming it once again from structures of the subjective consciousness (Berger 2011).

One part of the new era is the growth of pubs, especially in Pati, Central Java. In historical cultural studies, therefore, pubs are seen as an 
exemplary, if contested, site working-class during the period in which capitalism became consolidated in Britain. This concept underlies the theory based on contemporary life in Britain, in which pubs are symbolized as the decline of the country (Ashley 2004).

Although pub is considered as a site of disruption and danger, Richard's Hoggart's Uses of Literacy (1957) looks upon it as an authentic space of residual working-class sociality, against which the new and significantly Americanized space of the milk bar appears as a site of unprecedented aesthetic and social breakdown (Ashley 2004). Similarly, John Clarke (1979) nostalgically evokes a more authentic past when he analyses the drift towards oligopoly in the brewing industry and the shift in marketing ideologies towards attracting consumers. The pre-war working class stood in a relationship to the pub which he describes as "membership", in which the pub was 'a sort of colonized institution', the design and use of which had been molded by working-class patronage despite that class's lack of formal ownership (Ashley 2004).

The development of a brewing cartel, however, has led to a tendency for freeholders and tenants to be replaced by brewery-controlled managers, for pubs to be closed or redesigned, and for advertising to address previously excluded social groups: the new consumers differs from the old in terms of age, class, and taste (Ashley 2004). The effect of this attempt to address the new consumer is to fundamentally change the social and economic conditions under which drinking takes place these changes function to interpolate a new identity for drinker -that of the 'consumer ' rather than 'member' (Ashley 2004). In an attempt to reconstruct the "authentic" form of working-class culture, culturist writers are forced up against the highly structured conditions of cultural production in contemporary life (Ashley 2004). 


\section{The Geography of Pati}

Pati is a regency (Indonesian: Kabupaten) in the northeastern part of Central Java province in Indonesia. It covers an area of $1.489 .19 \mathrm{~km}^{2}$, and it had a population of 1.190 .993 at the 2010 Census; the latest official estimate (as at January 2014) is 1.205.601. Its administrative capital is the town of Pati (Oemar 1994).

The changing on the image of Pati into a city of thousand pubs invites problems because the pubs are not only used as refreshing places but also as prostitution places. The more serious problem is that the effect of the pub phenomenon on the increasing rates of divorce in Pati.

The growth of the pubs is caused by the emergence of karaoke pubs in Pati. Karaoke is originated from Japan. The word "karaoke" is actually an acronym for "kara" and "ok" means orchestra. However, in Indonesia, karaoke has experienced many shifts on its meaning. Since the beginning, the Indonesian people have the notion that karaoke is identical to nightclubs. Another opinion says that karaoke is a business providing spaces and facilities for singing supplemented by other services, such as food, beverages, and blind date.

\section{Behind the Story of "Prostitution" in Pati}

Talking about prostitution places in Pati, Kembang and Dukuhseti are two villages having long history with prostitution practice. Based on the history, the practice of prostitution in the village of Kembang and Dukuhseti, Pati Regency, Central Java was due to the arrival of Chinese and Portuguese migrant workers. These migrant workers stayed in the villages for quite long-term and made personal relationship with the women around the villages.

Besides the historical data about the prostitution practice in Pati, there is also a legend about Brojoseti-one of the prominent figures in a village in Pati-who had a very beautiful wife. However, his wife turned 
unfaithful and, thus, Brojoseti got angry. He cursed all the descent of his wife as well as all the people of the village to be disloyal to their spouses (Hull, Sulistyaningsih, and Jones 1997). As there is no concrete data about this legend, some people believe that the story of Brojoseti is only used to justify the practice of prostitution.

The political condition in Kembang and Dukuhseti villages in 1972 also influenced the growth of prostitution practice in Pati. At that time, women were exploited sexually based on the order of the village leader.

\section{The Reality of Pub Culture in Pati}

\section{Condition of Pub-Culture}

The data of karaoke pubs in Pati Regency based on the Hinder Ordonantie (HO) issued January 1.2000 - June 7, 2010 is as follows:

Table (1) HO of Pub Business

\begin{tabular}{|c|c|c|c|c|c|c|}
\hline No & Name of Pubs & Owner & Expired & HO Number & $\begin{array}{c}\text { Surface } \\
\text { Area }\left(\mathrm{m}^{2}\right)\end{array}$ & $\begin{array}{l}\text { Building } \\
\text { Area }\left(\mathrm{m}^{2}\right)\end{array}$ \\
\hline 1 & $\begin{array}{l}\text { Karaoke Ghiraz } \\
\text { Pati Wetan Village }\end{array}$ & Maria & $12-1-2010$ & $503 / 991 / 2001$ & 560 & 91 \\
\hline 2 & $\begin{array}{l}\text { Koplak } \\
\text { Margorejo Village }\end{array}$ & Martono & $\begin{array}{r}19-11- \\
2010 \\
\end{array}$ & $503 / 1006 / 2001$ & 355 & 64 \\
\hline 3 & $\begin{array}{l}\text { Milenium } \\
\text { Winong Village }\end{array}$ & $\begin{array}{l}\text { Santoso } \\
\text { Kartiyoso } \\
\end{array}$ & 14-3-2009 & $503 / 210 / 2003$ & 216 & 106 \\
\hline 4 & $\begin{array}{l}\text { Andri Yook } \\
\text { Kauman Village }\end{array}$ & Warijan & $\begin{array}{r}31-01- \\
2007 \\
\end{array}$ & $503 / 103 / 2004$ & 100 & 100 \\
\hline 5 & $\begin{array}{l}\text { Romantika } \\
\text { Ngarus Village }\end{array}$ & Zaenal M & $5-5-2010$ & $503 / 334 / 2004$ & 215 & 112 \\
\hline 6 & $\begin{array}{l}\text { CV.Gritary Griya P } \\
\text { Pati Kidul Village }\end{array}$ & $\begin{array}{l}\text { Ny. Sumarni } \\
\text { Purwant, S.H. }\end{array}$ & 22-6-2010 & $503 / 443 / 2004$ & 9075 & 2000 \\
\hline 7 & $\begin{array}{l}\text { Hotel Merdeka } \\
\text { Ngarus Village }\end{array}$ & SK.Hartono & $3-2-2008$ & $503 / 065 / 2005$ & 2895 & 1301 \\
\hline 8 & $\begin{array}{l}\text { Marimar } \\
\text { Margorejo Village }\end{array}$ & Kisawati & 20-3-2009 & $503 / 128 / 2006$ & 105 & 105 \\
\hline 9 & $\begin{array}{l}\text { Permata Music } \\
\text { Puri Village }\end{array}$ & Zaenal M & 20-6-2009 & $503 / 283 / 2006$ & 550 & 550 \\
\hline 10 & $\begin{array}{l}\text { Citra baru } \\
\text { Puri Village }\end{array}$ & $\begin{array}{l}\text { Wicaksono } \\
\text { B. Leksono }\end{array}$ & $\begin{array}{r}28-11- \\
2009 \\
\end{array}$ & $503 / 452 / 2006$ & 155 & 118 \\
\hline 11 & $\begin{array}{l}\text { The Boss Blue Be } \\
\text { Puri Village }\end{array}$ & Agus $\operatorname{Pr}$ & $5-2-2010$ & $503 / 49 / 2007$ & 1769 & 288 \\
\hline 12 & $\begin{array}{l}\text { Mars } \\
\text { Ngarus Village }\end{array}$ & Joko Mustiko & 28-6-2010 & $503 / 223 / 2007$ & 222 & 96 \\
\hline 13 & $\begin{array}{l}\text { Shinta } \\
\text { Pati Kidul Village }\end{array}$ & Ida Yufita & $16-7-2010$ & $503 / 250 / 2007$ & 782 & 185 \\
\hline
\end{tabular}




\begin{tabular}{|c|l|l|r|r|c|c|}
\hline 14 & $\begin{array}{l}\text { Larissa } \\
\text { Puri Village }\end{array}$ & A. P Astuti & $23-7-210$ & $503 / 254 / 2007$ & 100 & 100 \\
\hline 15 & $\begin{array}{l}\text { Rosalinda } \\
\text { Margorejo Village }\end{array}$ & Suharmono & $16-8-2011$ & $503 / 430 / 2008$ & 140 & 174 \\
\hline 16 & $\begin{array}{l}\text { Las Vegas } \\
\text { Margorejo Village }\end{array}$ & Deny P. & $2-4-2012$ & $503 / 181 / 2009$ & 2665 & 2065 \\
\hline
\end{tabular}

Source: Kanyandu Pati Regency (2010)

The data shows that there were 16 karaoke pubs in Pati regency since 2000 until 2010. The widest building is Las Vegas with $2.065 \mathrm{~m}^{2}$ and the narrowest is Koplak with $64 \mathrm{~m}^{2}$. The average of the building area is $465.94 \mathrm{~m}^{2}$. If each karaoke room requires $\pm 20 \mathrm{~m}^{2}$, the average number of the karaoke rooms is as many as 23 units, bringing the total reaches 368 units karaoke room. If each karaoke room requires 2 guides then the number of the labor force is assumed to reach 736 people.

\section{The License of the Karaoke}

While below are the data of the license of karaoke pubs in Pati regency based on the business license issued by the Department of Culture, Tourism, Youth and Sports (Disbudparpora):

Table (2) the Business License of the Karaoke Pubs in Pati Regency

\begin{tabular}{|c|c|c|c|c|c|}
\hline \multirow{2}{*}{ No } & \multirow{2}{*}{ Pub Names/Location } & \multirow[t]{2}{*}{ Owner } & \multicolumn{3}{|c|}{ Business License } \\
\hline & & & Number & Date & Expired \\
\hline 1 & $\begin{array}{l}\text { Marimar } \\
\text { Margorejo Village }\end{array}$ & Kiswati & $556.2 / 528$ & $09 / 07 / 2008$ & $09 / 07 / 2011$ \\
\hline 2 & $\begin{array}{l}\text { The Boss K } \\
\text { Winong Village }\end{array}$ & Agus Prastianto, & $556.2-607$ & $05 / 08 / 2008$ & 05/08/2011 \\
\hline 3 & $\begin{array}{l}\text { Mars Karaoke } \\
\text { Puri Village }\end{array}$ & Joko Mustiko & $556-2-526$ & $09 / 07 / 2008$ & $09 / 07 / 2011$ \\
\hline 4 & $\begin{array}{l}\text { Mutiara Indah K } \\
\text { Puri Residence }\end{array}$ & Joko Mulyo & $556-2 / 528$ & $09 / 07 / 2008$ & $09 / 07 / 2011$ \\
\hline 5 & $\begin{array}{l}\text { Citra Baru K } \\
\text { PJKA Pati }\end{array}$ & Wicaksono Bowo & $556-2 / 528$ & $09 / 07 / 2008$ & $09 / 07 / 2011$ \\
\hline 6 & $\begin{array}{l}\text { Las Vegas } \\
\text { Margorejo Village }\end{array}$ & Harmijadi & $\begin{array}{lcc}5 & 5 & 6 \\
2 / 0409 / 47\end{array}$ & $30 / 03 / 2009$ & $30 / 03 / 2012$ \\
\hline 7 & $\begin{array}{l}\text { K. Giraz } \\
\text { Pati Wetan Village }\end{array}$ & Maria & 556-2/528.A & $09 / 08 / 2007$ & $09 / 08 / 2010$ \\
\hline 8 & $\begin{array}{l}\text { K. Koplak } \\
\text { Margorejo Village }\end{array}$ & Martono & & & $\begin{array}{l}\text { has not been } \\
\text { renewed }\end{array}$ \\
\hline
\end{tabular}




\begin{tabular}{|c|l|l|l|l|l|}
\hline 9 & $\begin{array}{l}\text { K. Milenium } \\
\text { Winong Village }\end{array}$ & Santoso K & $556.2 / 053$ & $05 / 02 / 2010$ & $05 / 02 / 2013$ \\
\hline 10 & $\begin{array}{l}\text { K.Morsalino Htl, } \\
\text { Gritary P }\end{array}$ & Sumarni P & $556.2 / 071$ & $09 / 02 / 2010$ & $09 / 02 / 2013$ \\
\hline 11 & $\begin{array}{l}\text { K. Htl. Merdeka Pati } \\
\text { Village }\end{array}$ & SK. Hartono & $556.2 / 070$ & $09 / 02 / 2010$ & $09 / 02 / 2013$ \\
\hline 12 & $\begin{array}{l}\text { K. Romantika } \\
\text { Ngarus Village }\end{array}$ & Zaenal Musafak & $556.2 / 076.1$ & $05 / 09 / 2006$ & $05 / 09 / 2009$ \\
\hline 13 & $\begin{array}{l}\text { Permata Musik } \\
\text { Ngarus Village }\end{array}$ & Zaenal Musafak & $556.2 / 058$ & $08 / 02 / 2010$ & $08 / 02 / 2013$ \\
\hline 14 & Shinta K & Ida Yupita & $556.2 / 247$ & $29 / 03 / 2010$ & $29 / 03 / 2013$ \\
\hline
\end{tabular}

Sources: Disbudparpora Pati Regency (2010)

\section{Entertainment Tax}

Entertainment tax which is regulated in the Regional Regulation (Peraturan Daerah/PERDA) Pati No. 2 Year 1998 on entertainment tax, chapter II, article 3, paragraph 3, point e (karaoke) and chapter III, section 5 , letter e for karaoke set the taxt at 10\% (ten percent). In detail the realization of karaoke entertainment tax is as follows:

\section{Table (3) Entertainment Tax Realization from Karaoke Business}

\begin{tabular}{|c|c|c|c|}
\hline No. & Period & Tax Realization (Rp) & Growth (\%) \\
\hline 1 & 2007 & 64.994 .180 & 0.0 \\
\hline 2 & 2008 & 114.453 .210 & 0.76 \\
\hline 3 & 2009 & 244.273 .150 & 1.13 \\
\hline 4 & 2010 & 216.142 .900 & s/d Mei \\
\hline
\end{tabular}

Source: Disbudparpora Pati Regency (2010)

\section{Divorce Data}

\begin{tabular}{|c|c|c|c|c|c|c|c|c|c|}
\hline \multirow[t]{2}{*}{ No } & \multirow{2}{*}{$\begin{array}{c}\text { Pati Religious } \\
\text { Court }\end{array}$} & \multirow{2}{*}{$\begin{array}{l}\text { Number of } \\
\text { Divorces }\end{array}$} & \multicolumn{7}{|c|}{ Causes of Divorces } \\
\hline & & & $\begin{array}{c}\text { Morality } \\
\text { Crises }\end{array}$ & $\begin{array}{c}\text { Lose of } \\
\text { Respon- } \\
\text { sibility }\end{array}$ & Envious & $\begin{array}{l}\text { Dishar- } \\
\text { mony }\end{array}$ & $\begin{array}{l}\text { Third party } \\
\text { interference }\end{array}$ & $\begin{array}{l}\text { Other } \\
\text { Causes }\end{array}$ & $\begin{array}{l}\text { Anno- } \\
\text { tation }\end{array}$ \\
\hline 1 & January & 189 & 30 & 71 & 14 & 9 & 5 & 60 & \\
\hline 2 & February & 166 & 31 & 67 & 10 & 12 & 7 & 39 & \\
\hline 3 & March & 210 & 41 & 77 & 17 & 13 & 1 & 61 & \\
\hline 4 & April & 251 & 41 & 111 & 21 & 13 & 6 & 59 & \\
\hline 5 & May & 135 & 26 & 62 & 7 & 9 & 2 & 29 & \\
\hline 6 & June & 211 & 49 & 81 & 16 & 10 & 6 & 49 & \\
\hline 7 & July & 138 & 37 & 50 & 8 & 10 & 4 & 29 & \\
\hline 8 & August & 165 & 36 & 66 & 14 & 15 & 2 & 32 & \\
\hline
\end{tabular}




\begin{tabular}{|c|l|c|c|c|c|c|c|c|c|}
\hline 9 & September & 225 & 41 & 95 & 9 & 18 & 8 & 54 & \\
\hline 10 & October & 190 & 42 & 60 & 19 & 15 & 2 & 52 & \\
\hline 11 & November & 205 & 37 & 99 & 8 & 11 & 1 & 49 & \\
\hline 12 & December & 209 & 39 & 89 & 9 & 10 & 8 & 54 & \\
\hline \multicolumn{2}{|c|}{ Total } & $\mathbf{2 2 9 4}$ & $\mathbf{4 5 0}$ & $\mathbf{9 2 8}$ & $\mathbf{1 5 2}$ & $\mathbf{1 4 5}$ & $\mathbf{5 2}$ & $\mathbf{5 6 7}$ & \\
\hline
\end{tabular}

Source: Data of 2014.

Based on the above data, the author takes several hypothesizes. It seems that the causes of the divorces in Pati emerge as a result of the growth of the pubs in Pati. The above data show that the victims of pub culture are the people who live surrounding the pubs. According to an interview with a clerk in the religious court in Pati, in which the number of the divorces increases dramatically. However, the clerk did not dare to conclude that the increase of the divorces in Pati is due to the growth of pub culture in Pati.

\section{Conclusion}

The above pattern shows that there the growth of the pubs in Pati has been a culture. The closure of the pubs done by the local government was not able to be an effective way in restoring the image of the city as pubs have been a sporadic phenomenon for fifteen:

Myth: the famous legend of Brojoseti which is used as a mean of justification for some paties in conducting the practice of prostitution in Pati. Social Capital is the pubs give advantages for the local government as the revenue of the tax increased $0,95 \%$ until $1.12 \%$. Tourism, although there are a lot of potential tourist resorts in Pati, they have not been managed appropriately by the local government. On the other hand, there plenty pubs in this city. Consequently, the pubs are then selected as the tourist destinations. Religion, actually, there are many religious schools and institutions surrounding Pati. Thus, the image changing of the city raises anxiety to many parties, including the religious leaders and the people of Pati. Some organizations, such as Nahdlatul Ulama and Muhammadiyah, 
have forced the government to close the established karaoke and prohibit the other new pubs in Pati. Morality becomes very worrisome in this pubculture. In this case, the bad image is addressed to the pub-guides. As the pubs are now closed, there are no other recruitments for the job. Future of Next Generations in which the problem of pub culture in Pati is also bothersome for the next generations. If the pattern does not stop, the next generations will probably become the victims of the bad impact.

Religiosity of Pub-Culture, the legalization the pubs done by the local government does not solve the real problems. Because it doesn't solve the problem, religiosity is needed in order to restore the image of the city. 


\section{References}

Ambrose, Silvian D. 2006. Religion and Psychology: New Research. New York: Nova Science Publisher.

Ashley, Bob. 2004. Food and Cultural Studies. New York.

Berger, Peter L. 2011. The Sacred Canopy: Elements of a Sociological Theory of Religion. New York: Open Road Media.

Creighton-Smith, B.A., Cook, M., Edginton, C.R. 2017. Leisure, Ethics and Spirituality. Annals of Leisure Research 20 (5), pp. 546-562.

Dunbar-Hall, P. 2011.Village, Province, and Nation: Aspects of Identity in Children's Learning of Music and Dance in Bali in Learning, Teaching, and Musical Identity: Voices Across Cultures, pp.60-71.

Elias, J.J., Lacetera, N., Macis, M. 2015. Markets and Morals: An Experimental Survey Study. PloS ONE 10 (6), e0127069.

Gallardo-Peralta, L.P. 2017. The Relationship between Religiosity/ Spirituality, Social Support, and Quality of Life among Elderly Chilean People. International Social Work 60 (6), pp/ 1498-1511.

Gunby, C., Carline, A., Taylor, S. 2017. Location, Libation and Leisure: An Examination of the Use of Licensed Venues to Help Challenge Sexual Violence. Crime, Media, Culture 13 (3), pp. 315-333.

Lewis, Bernard. 2010. Faith and Power: Religion and Politics in the Middle East. London: Oxford University Press.

Maginn, P.J., Ellison, G. 2017. 'Ulster Says No’: Regulating the Consumption of Commercial Sex Spaces and Services in Northern Ireland. Urban Studies 54 (3), pp. 806-821.

Makela, E., Petsche, J.J.M., 2013. Serious Parody: Discordianism as Liuid Religion. Culture and Religion 14 (4), pp. 411-423.

Martin, Craigg. 2014. Capitalizing Religion: Ideology and the Opiate of the Bourgeoisie. London: Bloomsburry.

Oemar, Moh and friends. 1994. Oemar, Moh, and Friends. Jakarta: Depdikbud.

Pathan, S. 2016. Islamic spirituality and Social Work Interventions: The Person-in-Relation Approach. International Social Work 59 (3), pp. 406-418.

Perrin, Cindy Miller and Elizabeth Krumrei Mancuso. 2014. Faith from a Positive Psychology Perspective. Canada: Springer. 
Plambech, S. 2017. God Brought You Home-Deportation as Moral Governance in the Lives of Nigerian Sex Worker Migrants. Journal of Ethnic and Migration Studies 43 (13), pp. 2211-2227.

Souza, Marian de Souza, and friends. 2009. International Handbook of Education for Spirituality, Care and Wellbeing. Canada: Springer.

Tanner, R., Mitchell, C. 2016. Religion and the Environment. Springer International Publishing AG. Part of Springer Nature. 
DINIKA, Volume 2, Number 2, May - August 2017 